\title{
Facies, origin, and palaeontological inventory of an Early Carboniferous neptunian dyke in the Devonian reef limestone near Rösenbeck (Brilon Anticline, Rhenish Mountains)
}

\author{
F. Heuer ${ }^{1}$, D. Korn ${ }^{2}$, Z. Belka ${ }^{3}$, and V. Hairapetian ${ }^{4}$ \\ ${ }^{1}$ Fachbereich Geowissenschaften, Geotechnik und Bergbau, TU Bergakademie Freiberg, Bernhard-von-Cotta-Straße 2, \\ 09599 Freiberg, Germany \\ ${ }^{2}$ Museum für Naturkunde, Leibniz-Institut für Evolutions- und Biodiversitätsforschung, Invalidenstraße 43, \\ 10115 Berlin, Germany \\ ${ }^{3}$ AMU Isotope Laboratory, ul. Dziegielowa 27, 61-680 Poznan, Poland \\ ${ }^{4}$ Geology Department, Esfahan (Khorasgan) Branch, Islamic Azad University, P.O. Box 81595-158, Esfahan, Iran
}

Correspondence to: D. Korn (dieter.korn@mfn-berlin.de)

Received: 8 May 2014 - Revised: 21 December 2014 - Accepted: 3 January 2015 - Published: 23 January 2015

\begin{abstract}
The Devonian reef limestone complex of Rösenbeck near Brilon (Rhenish Mountains) shows numerous neptunian dykes and other hollows which have been filled with Carboniferous siliciclastic as well as fossil-rich carbonate sediments with ammonoids, conodonts, and chondrichthyan fish. While the shales of the infill can be interpreted as autochthonous sediments, the carbonates represent erratic blocks of sediments which were deposited in elevated areas but subsequently eroded and transported as erratic blocks into the karstic cavities. The biota of the carbonates demonstrates that two stratigraphic intervals are represented: (1) the Tournaisian-Viséan boundary interval, which can be identified by the presence of trilobites, and (2) the late Viséan (Asbian-Brigantian), proven by the presence of ammonoids and conodonts embedded in shales that probably have an early Serpukhovian age. Two carbonate facies can be distinguished in the Late Viséan blocks: (1) low-energy micritic sediments with Goniatites crenistria, which are probably equivalent to the crenistria Limestone and (2) high-energy (tempestite) sediments with numerous ammonoid specimens and in a more subordinate role other to fossil groups.
\end{abstract}

\section{Introduction}

Neptunian dykes and other karstic hollows in Devonian reef limestone formations are filled with a variety of younger sediments and have been attracting geoscientists for a long time. The dyke sediments are often fossil-rich and contain diverse faunas which are not known from time-equivalent sediments in normal sedimentary successions. Two occurrences of such Carboniferous infill have received particular attention in Germany: (1) the Erdbach Limestone at the classical Erdbach locality at the eastern margin of the Rhenish Mountains (e.g. Holzapfel, 1889; Stoppel et al., 2006) and (2) similar sediments recorded in outcrops on the Winterberg near the Iberg in the Harz Mountains (e.g. Schindewolf, 1951; Franke, 1973). Comparable occurrences in other regions, such as the Warstein Anticline and the Brilon Anticline of the Rhenisch Mountains, have not been as intensively investigated. Here we describe an occurrence of Carboniferous carbonate sediments within a karstic hollow on the Brilon Anticline.

The Brilon Massenkalk (Brilon carbonate complex, Fig. 1) is a massive limestone formation formed by reef detritus during the Middle Devonian (Givetian) and early Late Devonian (Frasnian) on a carbonate platform within the Rhenohercynian shelf (e.g. Franke, 2000). During the Late Devonian and Early Carboniferous, this platform began to break, particularly at its margins, with the formation of deep dykes, which were subsequently widened and filled with sediments of Carboniferous to Cretaceous age (e.g. Bär, 1966, 1968). Clausen 


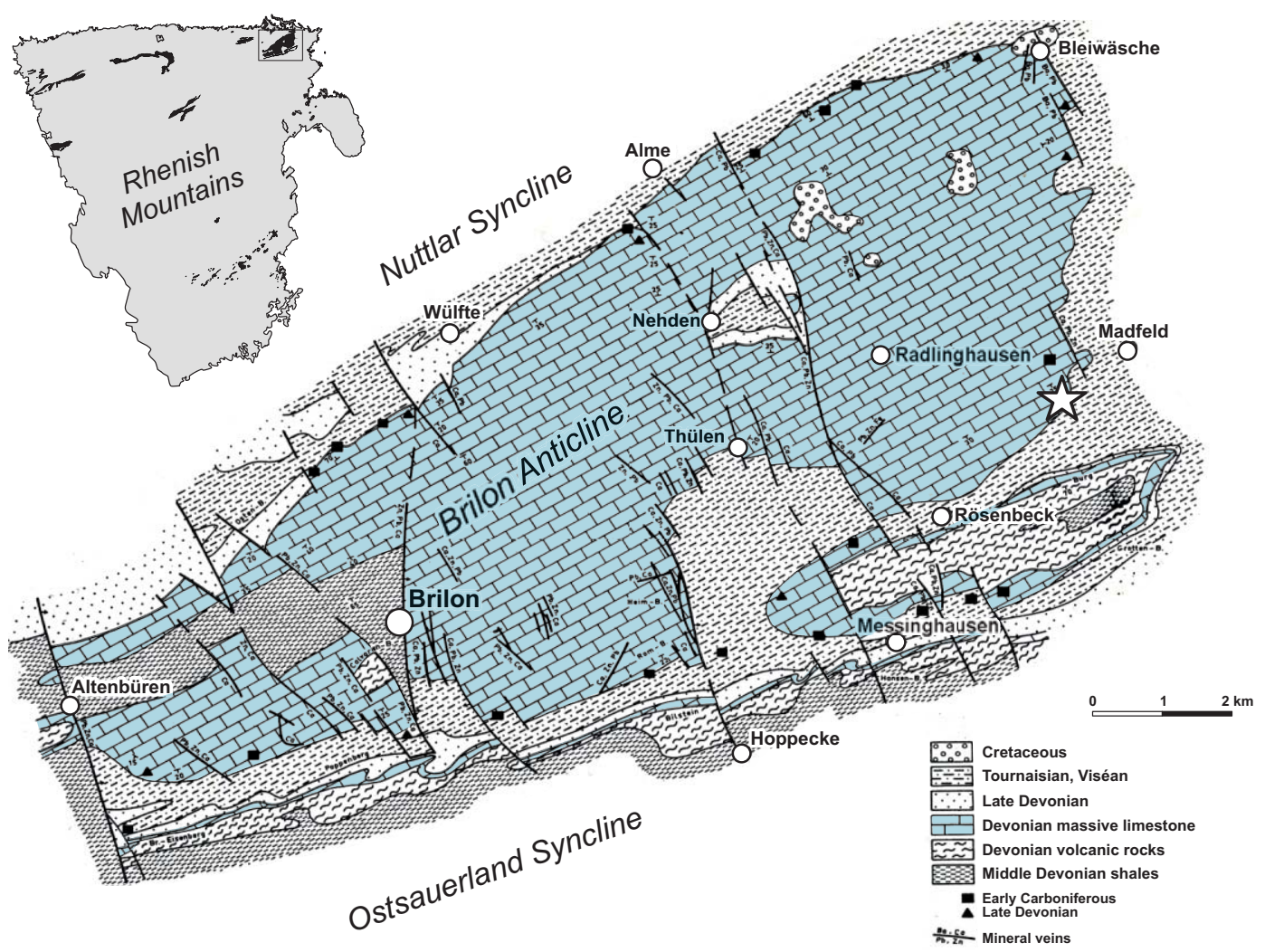

Figure 1. Geological map of the Brilon Syncline (after Bär, 1968) with the position of the Rösenbeck locality (marked by a star) at the eastern margin of the Brilon carbonate complex.

et al. (1978) as well as Clausen and Leuteritz $(1979,1984)$ described such occurrences on the Warstein Anticline.

Of particular interest are neptunian dykes and near-surface hollows filled with the so-called Erdbach Limestone, a peculiar rock formation that has already been described from classical localities such as Erdbach at the eastern margin of the Rhenish Mountains (e.g. Holzapfel, 1889; Krebs, 1968) or the Iberg in the Harz Mountains (e.g. Franke, 1973; Gischler, 1992). Most of these infills are late Tournaisian/early Visean in age (Ammonellipsites Zone in terms of ammonoids and Scaliognathus anchoralis Zone in terms of conodonts). However, younger Late Viséan neptunian dykes have been described from the vicinity of Rösenbeck (Bär, 1966, 1968; Brinckmann and Luppold, 2010; Brinckmann et al., 2015) and from the Iberg in the Harz Mountains (Gischler, 1992; Gischler and Korn, 1992).

The sediment infills of the neptunian dykes differ, with respect to their lithofacies and stratigraphic incompleteness, strongly from the "normal" basin facies in the surrounding areas. In the area of the Brilon Anticline, the basinal facies of the Late Viséan succession is developed as siliceous black shales and grey Posidonia-bearing shales with very thin limestone intercalations, which document a continuous sedimentary record as exposed in the road section south of Scharfenberg (Korn, 2010). A condensed shale succession was de- scribed by Pas et al. (2013) from the Burgberg, located only $1250 \mathrm{~m}$ south of the occurrence in the Rösenbeck quarry, but with a position on the northern flank of the Messinghausen Anticline. In the Burgberg quarry and also the section above the Beringhausen Tunnel on the south flank of the Messinghausen Anticline (Clausen et al., 1991; Schülke et al., 2003; Schülke and Popp, 2005), there occurs a more or less continuous succession from the Middle to the earliest Late Devonian reef limestone through to the Late Devonian nodular limestone. Both sections show an incomplete Carboniferous record. At Burgberg, the entire Tournaisian and large parts of the early Viséan are represented by only $4 \mathrm{~m}$ of dark shales (Pas et al., 2013), indicating that this succession is either extremely condensed or that substantial parts of it are missing.

The enlargement of the opencast limestone pit of Rheinkalk Messinghausen GmbH \& Co. KG, located northeast of Rösenbeck, created the possibility for a more detailed study of the neptunian dykes in the Devonian limestone complex (Fig. 2). This exposure enabled us to answer the following questions:

- Are the Carboniferous dyke sediments of Rösenbeck identical, in terms of carbonate facies, to the Erdbach Limestone? 
- Do the sediments in the neptunian dykes from Rösenbeck belong to a short stratigraphic interval, and do the sediments of Rösenbeck represent, like the Erdbach Limestone in other places, a stratigraphic interval situated at the Tournaisian-Viséan boundary?

In order to answer these research questions, we collected large samples of rock for sedimentological investigations and to study their biotic content (conodonts, ammonoids).

\section{Research history}

The investigation of the Brilon carbonate complex began in the 19th century with the pioneering studies by Sedgwick and Murchison (1842), Roemer (1844), and Stein (1860), as well as the first geological map of the area made by von Dechen (1884). These and later studies of the Brilon carbonate complex performed by Paeckelmann (1926) and Paeckelmann and Kühne (1936) did not provide any information on neptunian dykes with a Carboniferous infill.

It was probably Bär $(1966,1968)$ who first found Late Devonian and Early Carboniferous dyke sediments in the Brilon Massenkalk and regarded them as infill of palaeokarst voids. He demonstrated that Late Devonian and Early Carboniferous sedimentary rocks lie, at many places at the margin of the limestone complex, disconformably on the massive Middle Devonian limestone (Fig. 1). Moritz (1983) worked on drill cores in the Brilon Massenkalk complex and found fillings of various ages in the neptunian dykes.

Brinckmann and Luppold (2010) as well as Brinckmann et al. (2015) studied a number of localities with neptunian dykes in the area of Rösenbeck, including the outcrop described herein. They analysed the conodont faunas of the Carboniferous sediments and found species-rich, mixed faunas with elements of Frasnian to Serpukhovian age.

Fossiliferous carbonates of the Early Carboniferous age were discovered in other regions of the Rhenish Mountains. Holzapfel (1889) and Kayser (1907) investigated the reef complex of Langenaubach-Breitscheid in the Dill Syncline and described an irregularly thick Early Carboniferous limestone cover on top of the Devonian reef limestone. More than half a century later, Walliser et al. (1958) and Krebs (1960) interpreted these occurrences as neptunian dykes and coined the term Erdbach Limestone. In the type region of the Erdbach Limestone, Krebs (1968) described dykes with Early Carboniferous sediments and explained their origin through polyphasic submarine brittle tectonics. Füchtbauer and Richter (1983) interpreted the dykes as caused being by tectonic movements within the reef complex. Neptunian dykes with a Carboniferous infill were also reported from the Lahn Syncline (Buggisch and Michl, 2002).

Franke (1973) and Gischler (1992) investigated pockets and dykes filled predominantly with carbonate sediments on top of the Devonian Iberg reef in the Harz Mountains. These records have been known about for a long time (Roemer,
1850; Groddeck, 1883), and ammonoids from these occurrences at the Winterberg have already been described by Schindewolf (1951) as well as Eichenberg and Schneider (1962), who compared these with the fauna from Erdbach. It was shown that the ammonoid faunas from the Winterberg belong to at least three stratigraphic levels (Gischler and Korn, 1992): (1) the Tournaisian-Viséan boundary interval (fauna with Merocanites like at Erdbach), (2) the basal Brigantian (fauna with Goniatites), and (3) the middle Brigantian (fauna with Neoglyphioceras).

Thick limestone beds with Early Carboniferous conodonts led Uffenorde $(1976,1977)$ to postulate the independence of a massive Early Carboniferous limestone formation ("Kallenhardt Limestone") within the Warstein limestone complex. He revised his idea and pointed out that the conodonts probably were derived from millimetre-wide fissures in the Erdbach Limestone (in Clausen et al., 1982). Macrofossils have not been reported so far from the Carboniferous dyke sediments of the Warstein Anticline (Clausen and Leuteritz, 1984).

At the eastern margin of the Warstein Anticline, Krebs and Wachendorf (1979) investigated the so-called Schlagwasserbrekzie, which they interpreted as the lateral equivalent of the Erdbach Limestone. This breccia was seen as a polymictic conglomerate composed of fragments of cephalopod limestone, flint limestone, and massive reef limestone embedded in a marly matrix. Clausen and Leuteritz (1984) discovered large dykes filled with breccias and boulders in the massive Devonian limestone of the Warstein Anticline. They interpreted this infill as stratigraphically and related to the Schlagwasserbrekzie.

Stoppel et al. (2006) pointed out that various carbonates in the Rhenish Mountains were regarded as Erdbach Limestone, as long they came from the Tournaisian-Viséan boundary interval. They limited the original concept of the term Erdbach Limestone to the crinoid-rich limestone facies with abundant cephalopods, bivalves, gastropods, and trilobites deposited on the Devonian reefs after their decline. They discovered that the Erdbach Limestone is not a formation within a continuous succession of sedimentary rocks but rather a locally delimited rock unit of maximally $10 \mathrm{~m}$ thick which had been accumulated on the rugged surface of the Devonian reefs or deposited as an infill of dykes and caves. According to this new, narrower definition, the bedded Erdbach Limestone with conodonts, echinoderms, gastropods, brachiopods, cephalopods, trilobites, and corals of the Warstein Anticline does not belong to the Erdbach Limestone. This rock unit, best exposed on the northern flank of the Warstein Anticline (Drewer, Kattensiepen, Eulenspiegel), was named the Kattensiepen Member by Korn (2006).

Several authors studied the fauna of the Erdbach Limestone. The first of these was Holzapfel (1889), who described ammonoids, brachiopods, corals, and trilobites from the type locality near Erdbach. Richter and Richter (1949), Hahn (1967), and Hahn et al. (1996) investigated the trilo- 

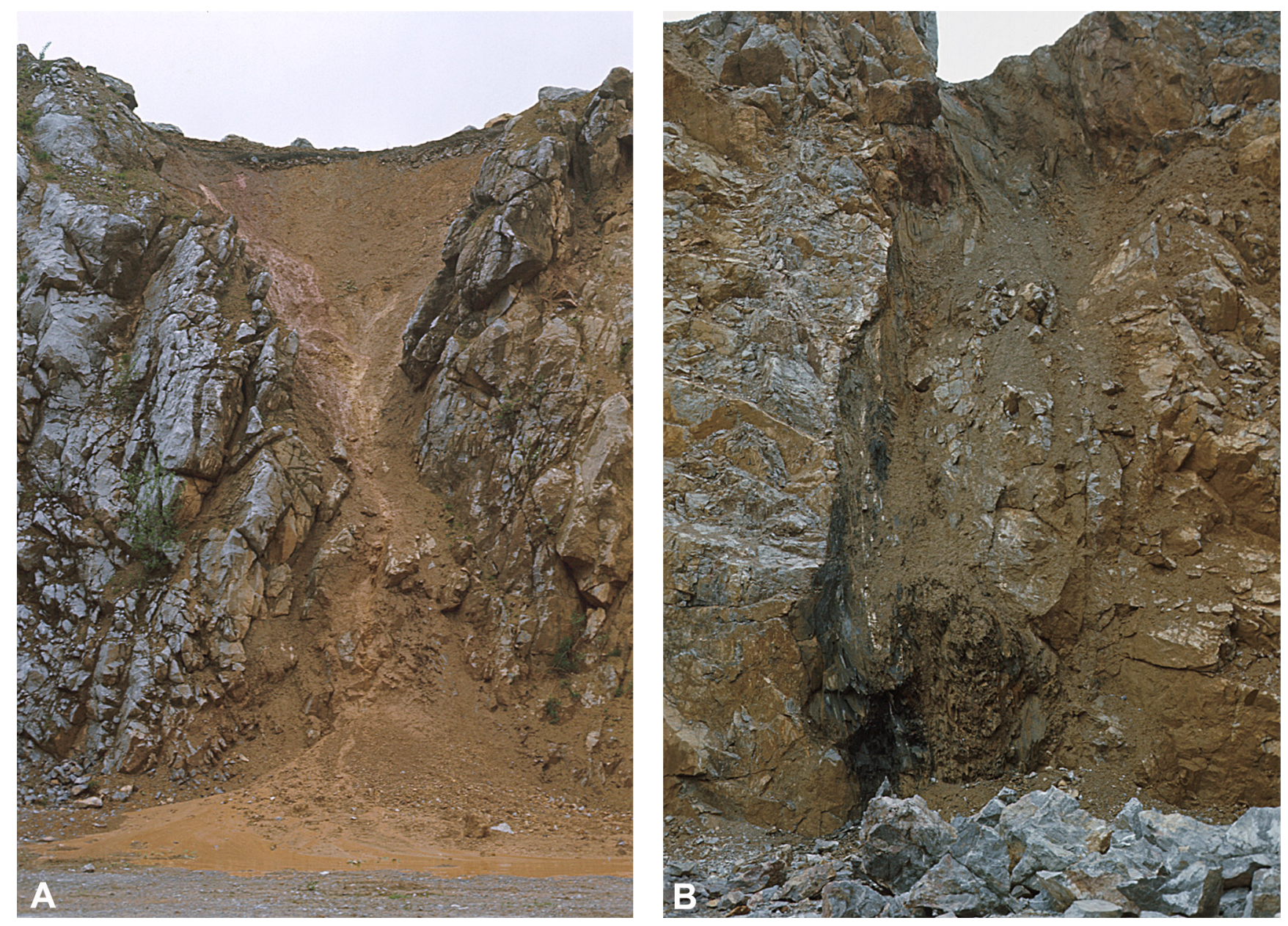

Figure 2. Examples of neptunian dykes in the Middle Devonian limestone in the Rösenbeck quarry. (a) Funnel-shaped dyke largely filled with debris and mud. (b) Cave-like dyke filled with Early Carboniferous shales.

bite fauna. The conodonts from localities near Erdbach were studied by Krebs (1962), who then used these data to distinguish three successive horizons (Erdbach Limestone I, II, and III) in the type locality (Krebs, 1968). The ammonoids from the time-equivalent carbonates of the Erdbach type in the Harz Mountains were described by Schindewolf (1951) and the crinoids by Sievert-Doreck (1951).

Amler et al. (2004) described the macrofauna of the Erdbach Limestone as typical for small-scaled diverse environments on seafloor elevations, which are considerably different from the surrounding basins. Based on sedimentological features they interpreted the Erdbach Limestone as being characterised by slow accumulation rates in a shallow but low-energy environment.

In several studies it was demonstrated that the Carboniferous sedimentary rocks of the Iberg reef in the Harz Mountains are much more diverse than time equivalents in other regions. Peckmann et al. (2001), Gischler et al. (2003), and Buggisch and Krumm (2005) postulated a cold seep environment for the accumulation of low-diversity but high- abundance fossil assemblages, particularly of rhynchonellid brachiopods and solemyid bivalves.

\section{Sample locality and material}

The Brilon Anticline is located in the north-eastern corner of the Rhenish Mountains (Fig. 1). This structure is predominantly formed by a massive Devonian limestone formation ("Massenkalk"), the exposures of which extend over a distance of $17.5 \mathrm{~km}$, from Altenbüren in the south-west to Bleiwäsche in the north-east. The sample locality $\left(51.42455^{\circ} \mathrm{N}\right.$, $8.70933^{\circ} \mathrm{E}$ ) within the large opencast mine of Rheinkalk Messinghausen $\mathrm{GmbH} \& \mathrm{Co}$. KG is situated at the eastern margin of the limestone occurrence, $2.5 \mathrm{~km}$ north-east of the town of Rösenbeck, $10 \mathrm{~km}$ east-north-east of Brilon. In this large quarry, numerous neptunian dykes and other karstic hollows are exposed (Fig. 2). Most of them are filled with clay and loose boulders, but one narrow dyke shows, at least $60 \mathrm{~m}$ below the current surface, an infill composed of black shales of unknown stratigraphic age (Fig. 3). 


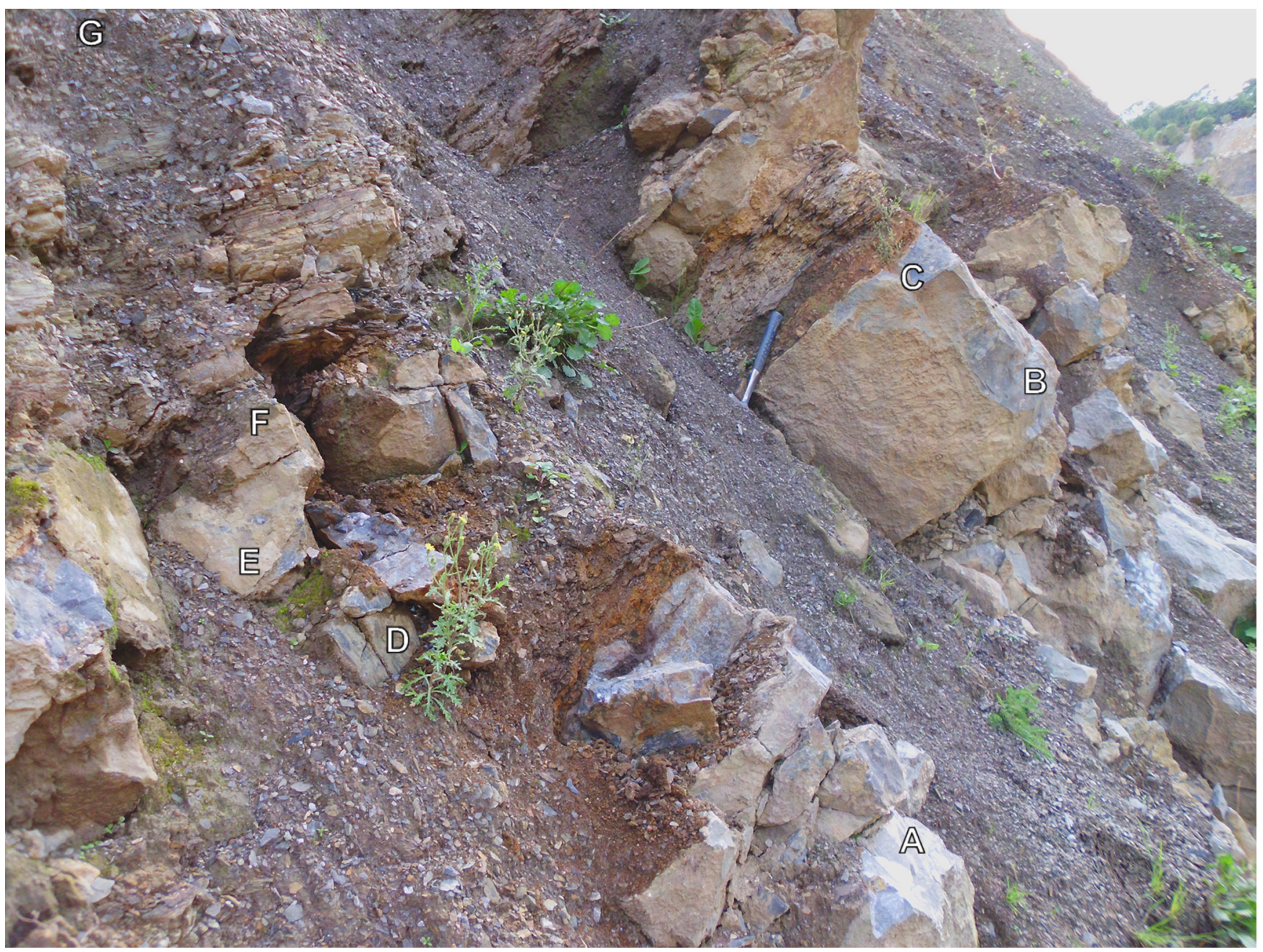

Figure 3. The position of the studied samples in the outcrop at the south-eastern margin of the limestone quarry. Sample A is from the top of the Middle Devonian reef limestone, and samples B to G are Early Carboniferous dyke sediments.

The karstic cavity in the Devonian limestone complex has been exposed for at least 25 years, but only the enlargement of the quarry has allowed for more detailed sampling. The investigated samples are from a northward-facing quarry face, 6 to $8 \mathrm{~m} \mathrm{high}$, at the eastern margin of the large opencast pit. This occurrence is situated only about $100 \mathrm{~m}$ west of the significant $\mathrm{N}-\mathrm{S}$-tending fault system that delimits the Devonian carbonate complex from Serpukhovian siliciclastics. At this place, the Devonian massive limestone possesses an at least $80 \mathrm{~m}$ wide, irregularly funnel-shaped cavity, which is truncated by erosion at the top. This hollow is filled with dark-grey but often strongly bleached shales with nearly horizontal bedding and containing numerous isolated blocks of Middle Devonian and Early Carboniferous limestones.

The topography of the contact between the massive Devonian limestone and the dark Carboniferous shales probably reflects the relief during the Early Carboniferous. Only at one place can a direct contact of the Devonian limestone with the overlying Carboniferous carbonates be seen (Fig. 3).
However, the outcrop clearly shows that a natural sedimentary contact is not present here and that the Carboniferous limestone beds represent large erratic blocks.

During the present study, eight samples (A to H), which were collected in 2011 from the aforementioned outcrop, were investigated (Fig. 3):

- A - Sample from the top part of the Devonian massive limestone near the contact with the overlying Carboniferous carbonates.

- B, C - Samples from a very large limestone body of up to $65 \mathrm{~cm}$ thickness which lies with uneven contact on the Devonian massive limestone and quickly wedges out to the sides. Sample B was taken from the base and sample $\mathrm{C}$ from the top of this limestone bed.

- D - Sample from an about $20 \mathrm{~cm}$ thick irregular limestone bed which is separated from sample B and C by 


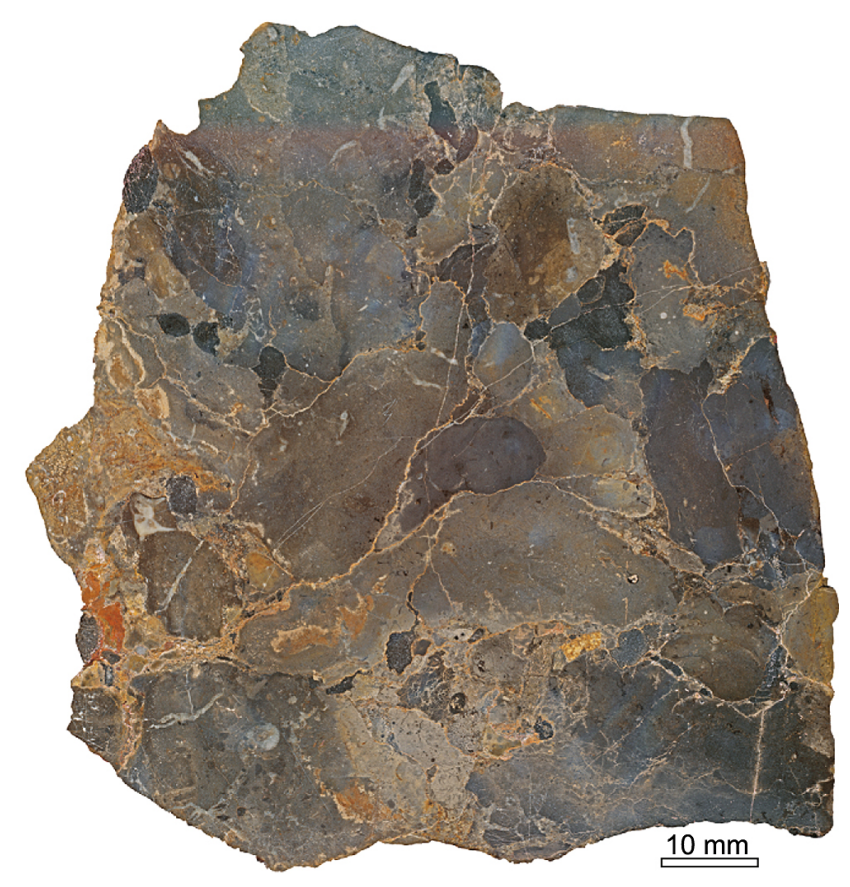

Figure 4. Polished slab of sample E showing a breccia structure with various carbonate and phosphorite components; $\times 1$.

up to $40 \mathrm{~cm}$ of dark-grey and, particularly at the base, rust-coloured shales.

- E, F - Samples from a very irregular, limestone breccia with up to $30 \mathrm{~cm}$ thickness (Fig. 4) which is separated by thin rust-coloured shales from the bed of sample D.

- G, H-Large isolated blocks of a limestone bed reaching a thickness of up to $60 \mathrm{~cm}$ embedded in grey shales.

An additional sample (sample X) was taken in 1988 by D. Korn from an isolated large block of about $1 \mathrm{~m}$ length. This block was found only a few metres away from the new outcrop and may have been derived from the same neptunian dyke. It was a marly carbonate with extremely common trilobite remains, which are being studied by Hahn and Müller and have a latest Tournaisian/earliest Viséan age.

\section{Carbonate microfacies}

Large polished slabs (up to $15 \times 15 \mathrm{~cm}$, Fig. 4) and thin sections (up to $5 \times 5 \mathrm{~cm}$, Fig. 5) were produced for the microfacies analysis. Classifications of carbonate rocks of Dunham (1962) and Embry and Klovan (1972) were used to characterise the investigated samples.

- A - Stromatopora-Tabulata rudstone with numerous biogens (stromatoporoids, tabulate corals (Thamnopora), a few bivalves and singular crinoid ossicles); it represents the typical reef debris facies widespread in the Brilon Anticline (Fig. 5a).
- B, C - We studied larger slabs of this bed, which shows various lithofacies (Fig. 5b-d). The bed is developed as an ammonoid packstone with various bioclasts such as bivalves, orthocone cephalopods, gastropods, trilobites, ostracods, foraminifera, fish remains, crinoids, conodonts, and lithoclasts (mostly angular extraclasts and phosphoritic nodules). The strongly fragmented bioclasts and lithoclasts are usually poorly sorted and randomly oriented. The bed has several internal erosional surfaces, sometimes underlined by pressure solution sutures. It is interpreted as representing multiple tempestites with re-sedimentation of bio- and lithoclasts.

- D - The sample is a fine-grained, dark-grey, and nearly homogeneous limestone. It can be described as an ammonoid-bearing wackestone with a few fragmented biogens and a few ammonoid conchs, which exhibit little fragmentation. In its lithology and biota, this carbonate closely resembles the crenistria Limestone, which occurs throughout the Rhenish Mountains and the Harz Mountains (Mestermann, 1998).

- E, F, H - The samples represent a carbonate breccia composed of angular as well as rounded components, which are randomly oriented. The spectrum of clasts comprises fragments of Devonian reef limestone, Carboniferous mudstone and wackestone (comparable to sample D), Carboniferous ammonoid packstone (such as samples B and C), and phosphoritic nodules. The lithology of the samples attests to an extensive resedimentation under high-energy depositional conditions. Most probably the bed was accumulated as a breccia within the cavity.

- G - The carbonate closely resembles that of the sample $\mathrm{D}$, but differs in more frequent biogens, particularly of ammonoids (Fig. 5f). The matrix is micritic, and ammonoids (probably Goniatites crenistria) are irregularly distributed with some concentrations. Other biogens are rare bivalves (Posidonia) and rugose corals. The bed is very similar to the crenistria Limestone but reaches a thickness of $60 \mathrm{~cm}$ in the outcrop of Rösenbeck. Rounded blocks of this limestone occur irregularly in the shales filling the cavity within the Devonian limestone; it is clear that they were transported into the karst hole.

\section{Selected fossil groups}

\subsection{Ammonoids}

Despite the richness of ammonoid specimens, only a few determinable individuals could be extracted from the hard carbonate rocks. Nevertheless, the polished slabs and the thin 
sections allow for insight into the composition of the fauna. Two faunas can be separated:

1. In samples $\mathrm{D}$ and $\mathrm{G}$, only one goniatite species is represented (e.g. Fig. 5f). According to the conch shape, these specimens should be determined as Goniatites crenistria Phillips, 1836 . This can be seen as further evidence that the samples are an equivalent of the crenistria Limestone (Warnke, 1997; Mestermann, 1998).

2. Samples B, C, E, and F show an abundance of ammonoids, and most of them belong to the genus Goniatites, most probably Goniatites fimbriatus (Foord and Crick, 1897) or Goniatites spirifer Roemer, 1850, together with Calygirtyoceras sp. (Fig. 5e).

The shales filling most of the large cavity are very poor in fossils, and hence the biostratigraphic interpretation is very difficult. Apart from small bivalves ("Posidoniella", which may speak for a basal Serpukhovian age), a juvenile specimen of a coelacanth has been found (Witzmann et al., 2010). This means that the carbonates are obviously older than the shales in which the carbonate blocks are embedded (Fig. 6).

\subsection{Conodonts}

Brinckmann and Luppold (2010), in their study of the investigated outcrop, identified conodont assemblages from two successive limestone horizons. The lower one contained a mixed fauna with Frasnian (Late Devonian) to Early Carboniferous taxa, whereas the fauna of the upper horizon was indicative of the latest Visean to early Serpukhovian age. These findings confirmed an earlier study of Bär (1968), who reported mixed faunas from the post-Devonian carbonate cover overlying the Brilon limestone complex.

In the present study six samples (B to $F$ and $H$ ), each about $1 \mathrm{~kg}$, were dissolved in dilute formic acid. Conodonts are very common, with more than 1100 disjunct platform elements of Lochriea and Gnathodus (Fig. 7, Table 1). The fauna includes exclusively Viséan forms, which are mostly long-ranging species. Three samples include taxa that allow for very accurate biostratigraphic dating. The co-occurrence of the species Lochriea nodosa and Gnathodus praebilineatus in samples $\mathrm{C}$ and $\mathrm{F}$ is indicative of the lowest part of the nodosa Zone (Belka and Lehmann, 1998; Nemyrovska, 2005). There is no doubt that the sample $H$ represents the same stratigraphic interval. The zonal marker L. nodosa is admittedly absent but the fauna contains the taxa $G n$. praebilineatus and Mestognathus bipluti, the stratigraphic ranges of which overlap within a short interval at the base of the nodosa Zone only. Conodont fauna found in the sample B is also characteristic of the nodosa Zone. Its composition, however, is not specific to any particular part of the zone. The assemblages of the samples D and $\mathrm{E}$ are very poor. In general, the appearance of gnathodid forms, Gn. prebilineatus, Gn. bilineatus, and Gn. girtyi, is characteristic of faunas of the bi- lineatus conodont Zone, but it cannot be excluded that these samples also represent the lower part of the nodosa Zone.

\subsection{Fish remains}

Processing of samples for microfossils revealed a number of fish microremains which can be attributed to various chondrichthyan groups including representatives of Symmoriiformes, Squatinactiformes, Phoebodontiformes, and Holocephali (Fig. 8). The teeth have been determined as belonging to Denaea cf. fournieri Pruvost, 1922; Thrinacodus cf. gracia (Grogan and Lund, 2008); ?Squatinactis sp.; and Holocephali indet. Associated with the teeth are ctenacanth- and hybodont-type scales and spines.

A large number of the falcatid teeth of cladodont design, assigned to Denaea, probably suggest an offshore assemblage. Other taxa would seem to be rare visitors to the waters covering the Rhenohercynian shelf due to a very low amount of collected material. Similar chondrichthyan assemblages, but rather more diverse ones, are also known from the Late Viséan sediments of Poland, Germany, and England (e.g. Ginter et al., 2010, 2015).

\section{Results}

\subsection{Genesis of the Carboniferous neptunian dykes}

The development of the Brilon carbonate complex began in the Middle Devonian with the onset of reef building, and until the early Late Devonian, a large Tabulata-Stromatopora biostrome had been built up (e.g. Paeckelmann and Kühne, 1936; Krebs, 1967, 1971; Machel, 1990). During the Givetian and early Frasnian, an extended carbonate complex of approximately $80 \mathrm{~km}^{2}$ and $300 \mathrm{~m}$ thick was accumulated. The death of the reef has been dated, as in other parts of the Rhenohercynian Basin, to the Frasnian (Jux, 1960).

During the Famennian and Tournaisian, the carbonate complex experienced some disruptions, particularly at its margins, paralleled by the formation of fissures and cracks (Fig. 9). Time-equivalent sedimentary rocks in normal succession are only known from the Nehden Syncline (which forms a window in the Brilon Massenkalk, Fig. 1) and from the Messinghausen Anticline, but there they are in a succession above the Devonian reef limestone (Schülke and Popp, 2005; Pas et al., 2013). At the end of the Tournaisian, condensed carbonate sediments (Erdbach Limestone facies) were occasionally accumulated on the surface of the reef ruin. A loose block of this age was found by D. Korn in 1988, containing numerous trilobites of latest Tournaisian to earliest Viséan age (P. Müller, personal communication, 2013).

In the Late Viséan, the second phase of accumulation of condensed carbonate sediments led to the formation of two different carbonate facies and phosphorite nodules on top of the reef ruin. 

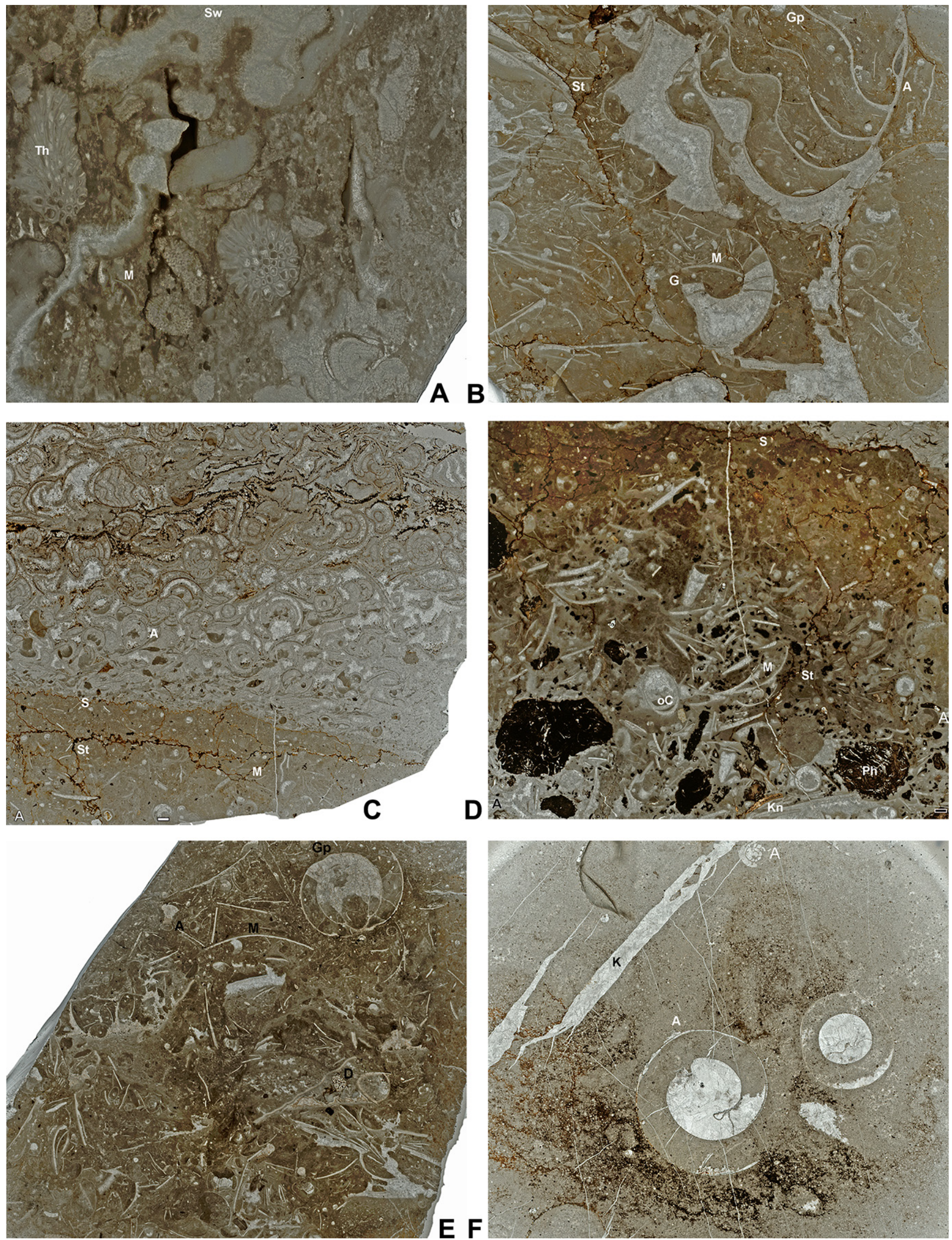
Figure 5. Carbonate microfacies of selected samples from the Rösenbeck quarry; all $\times 2$. A - Middle Devonian reef limestone; B-F - Early Carboniferous dyke sediments. (a) Sample A: Stromatopora-Tabulata rudstone. Bioclast- and lithoclast-supported facies with fragments of stromatoporoids, tabulate corals (Thamnopora), and fragments of rugose corals and bivalves without preferred orientation. (b) Sample B: ammonoid packstone. Densely packed fragments of ammonoids within micritic matrix; some areas are filled with pseudosparite. Bioclast voids are filled with sparry calcite and displaying geopetal orientation. Ammonoids of various sizes from the initial stage (1 mm in diameter) up to $20 \mathrm{~mm}$ (but then fragmentary) are packed without preferred orientation. Numerous mollusc shell fragments (probably also mostly from ammonoids); less abundant are remains of ostracods, trilobites, and foraminifera. (c) Sample C: thin section with two successive carbonate facies. The lower part is a mollusc packstone with micritic matrix in which particularly small ammonoids up to 2 mm diameter are present; larger specimens are fragmented. Separated by a sharp boundary follows (in the upper part of the thin section) an ammonoid rudstone with densely packed ammonoids up to approximately $8 \mathrm{~mm}$ conch diameter. (d) Sample C: densely packed bioclastic and lithoclastic packstone with strongly fragmented mollusc shells and well-rounded clasts of phosphoritic nodules up to $10 \mathrm{~mm}$ length. Further biogens include ostracods, foraminifera, and conodonts. (e) Sample E: mollusc packstone with micritic matrix, which in some places is replaced by pseudosparite. Bioclast voids are filled with sparry calcite and show geopetal orientation. Most of the bioclasts are probably ammonoid shell remains; only one specimen is rather well preserved with internal whorls (Calygirtyoceras sp.). Further biogens are orthoconic cephalopods, ostracods, and trilobites. (f) Sample G: wackestone with occasionally occurring ammonoid conchs.

Table 1. Numerical distribution of platform elements of conodont species recovered from limestone blocks at Rösenbeck.

\begin{tabular}{lrrrrrr}
\hline Conodont species & Sample B & Sample C & Sample D & Sample E & Sample F & Sample H \\
\hline Gnathodus bilineatus & - & 8 & - & 1 & 16 & 16 \\
Gnathodus girtyi collinsoni & 2 & 9 & - & - & - & - \\
Gnathodus girtyi girtyi & 63 & 163 & 7 & - & 44 & 197 \\
Gnathodus praebilineatus & - & 6 & 3 & 1 & 4 & 11 \\
"Gnathodus" homopunctatus & - & 9 & 6 & 1 & 102 & 101 \\
Gnathodus spp. & 6 & 5 & 4 & 1 & 16 & 6 \\
Mestognathus bipluti & - & - & - & - & - & 1 \\
Lochriea commutata & 6 & 23 & 6 & 2 & 125 & 156 \\
Lochriea mononodosa & - & 7 & - & - & - & - \\
Lochriea nodosa & 2 & 8 & - & - & 2 & - \\
\hline Total specimens & 79 & 238 & 26 & 6 & 309 & 489 \\
\hline
\end{tabular}

1. The first carbonate facies can be attributed to the crenistria Limestone (Goniatites crenistria Zone) and thus closely resembles the basinal facies of the Rhenohercynian Basin; it falls within the maximum flooding interval of the late Asbian (Herbig et al., 1999).

2. The second facies consist of tempestites that are stratigraphically slightly younger (Goniatites fimbriatus Zone or Goniatites spirifer Zone) than the first; it belongs in the lowstand systems tract of the early Brigantian.

Subsequently, the filling of the karstic cavities of Rösenbeck began; background sediments (predominantly clay) as well as blocks of the host carbonates (Devonian reef limestone) and the cover sediments (Carboniferous carbonates) were transported into the dykes. This caused a repeated succession of high-energy carbonates (samples B, C, E, and F) with low-energy carbonates (samples D, G, and H) separated by shales. The stratigraphical inversion speaks for an allochthonous origin of these blocks, which were probably transported into the dykes after the collapse of the palaeokarst. Unfortunately, the outcrops near Rösenbeck do not allow for the study of the Carboniferous carbonates at the place of their initial sedimentation.

There is some evidence that Early Carboniferous carbonates were also accumulated deep in the neptunian dykes, as in the small Stemmel quarry only $650 \mathrm{~m}$ north-west of the occurrences described here (Brinckmann and Luppold, 2010; Brinckmann et al., 2015). Such an in situ occurrence of carbonates is not known from the Rösenbeck quarry; the deepest of the exposed dykes (Fig. 2b) is filled with dark shales. It can therefore be assumed that most of the Early Carboniferous carbonates were built up on top of the dead reef, and that loose blocks were transported during the collapse of the topographic structure for re-sedimentation within the karstic structures.

Most probably, the neptunian dykes in the area of Rösenbeck were enlarged in post-Carboniferous times. Deep hollows filled with Cretaceous sediments are filled with glauconite sandstone in the Warstein Anticline (Clausen et al., 1978; Clausen and Leuteritz, 1979, 1984) and dinosaurbearing clay near Nehden in the Brilon Anticline (Huckriede, 1982; Norman, 1987). In the Rösenbeck quarry, younger dykes are filled with silt and boulders or by mineral veins (usually quartz and haematite). 


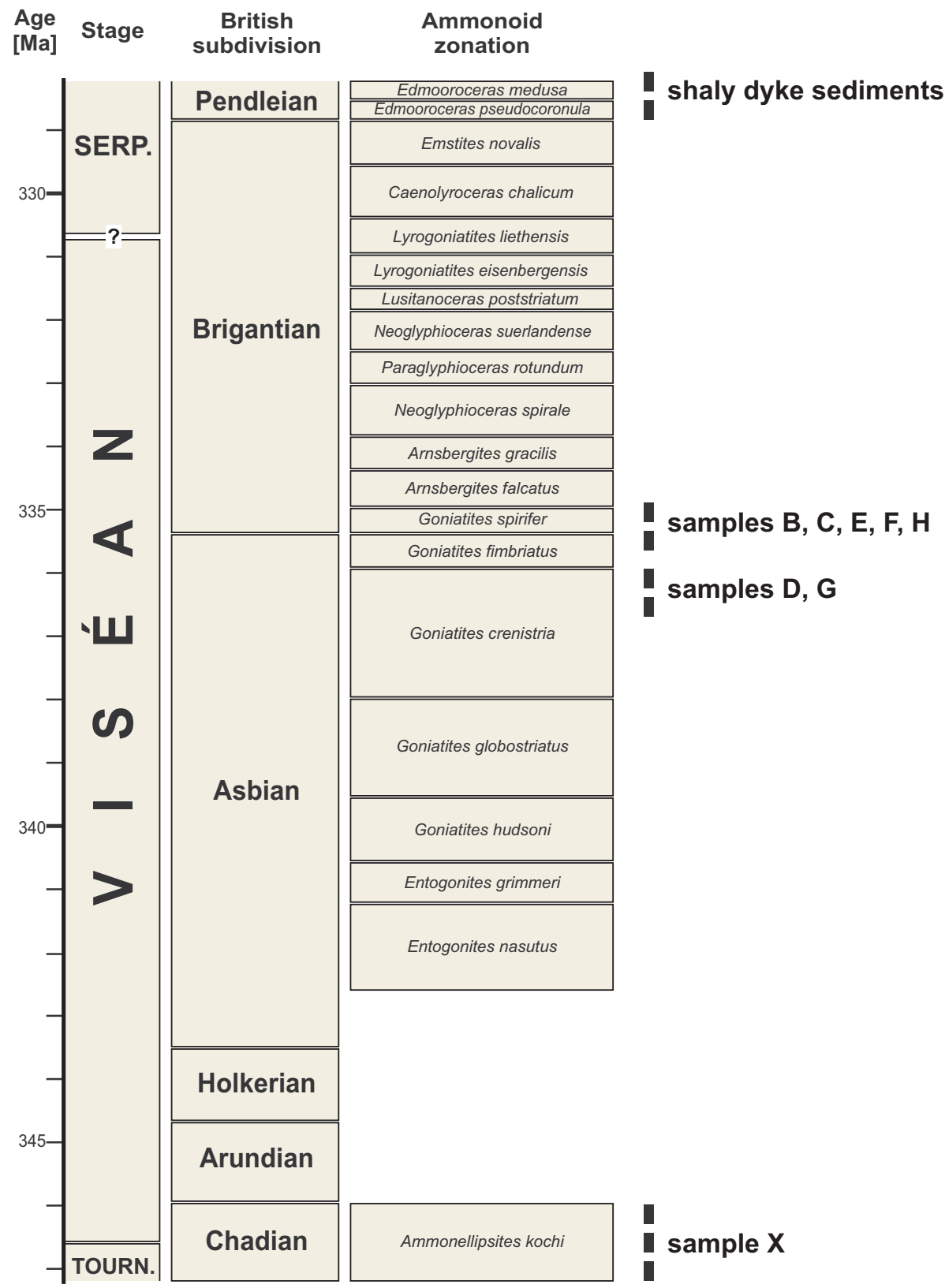

Figure 6. Stratigraphic column for the Viséan with the ammonoid stratigraphy and the presumed positions of the samples (timescale after Korn and Kaufmann, 2009).

\subsection{Discussion of the hypotheses}

The following questions can be answered according to the study of the neptunian dyke carbonates from Rösenbeck:

1. Are the Carboniferous cover sediments of Rösenbeck identical, in terms of carbonate facies, to the Erdbach Limestone?

With respect to the composition of the macrofauna, the Rösenbeck occurrence resembles the classical Erdbach Limestone mainly in the abundant occurrence of am- monoids, but other typical faunal elements from Erdbach (trilobites, echinoderms, and corals) are considerably rare in most of the samples from Rösenbeck Only sample X, which was collected from a loose block, contained many trilobites and echinoderms and thus shows a closer resemblance to the Erdbach Limestone. The definition of the Erdbach Limestone (Stoppel et al., 2006) as a crinoid-rich limestone with many ammonoids, bivalves, gastropods, and trilobites does not apply to samples A to $\mathrm{H}$. 

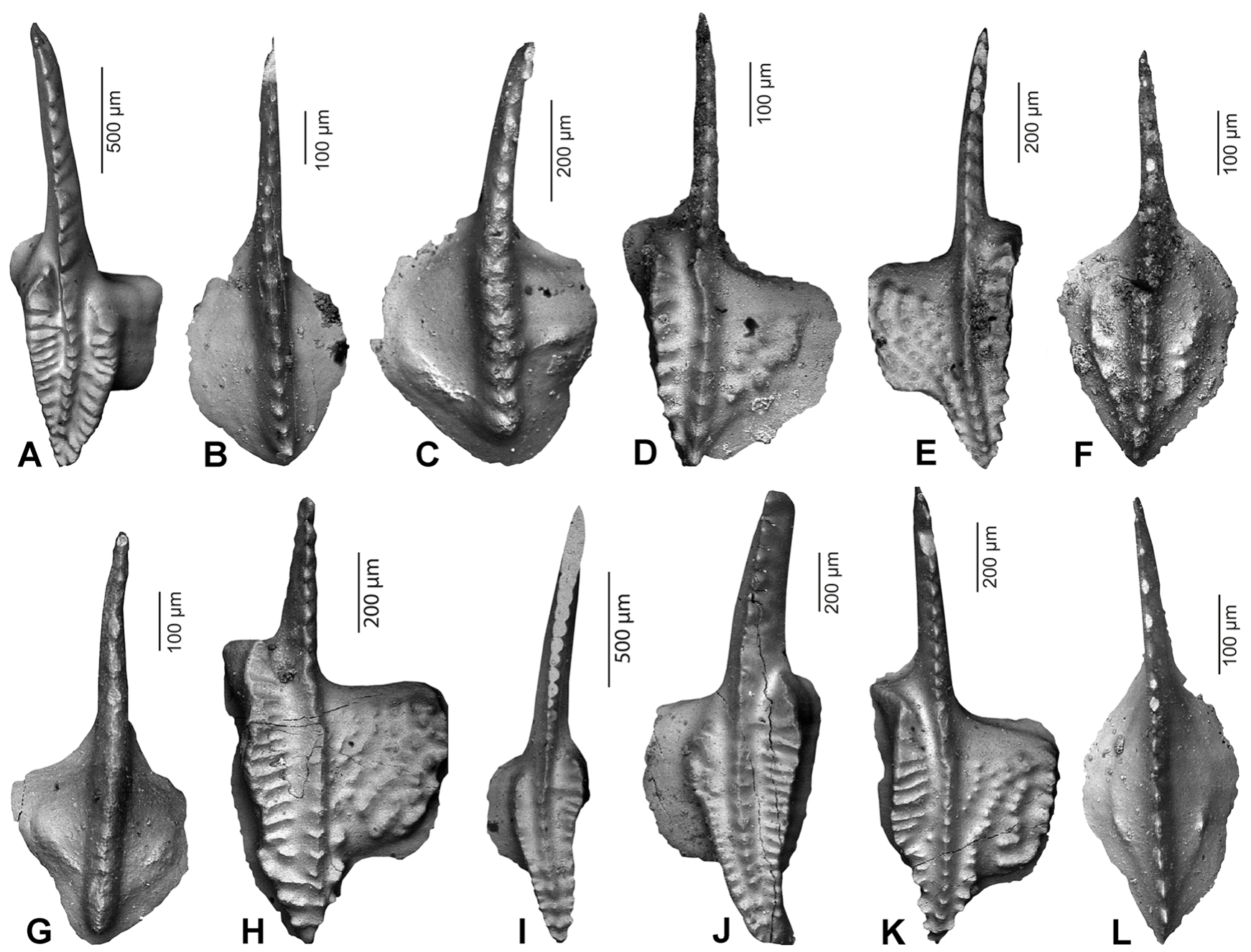

Figure 7. Conodonts from the Early Carboniferous dyke sediments of Rösenbeck. (a) Gnathodus girtyi girtyi Haas, 1953, sample C. (b) Lochriea commutata (Branson and Mehl, 1941), sample C. (c) Lochriea nodosa (Bischoff, 1957), sample C. (d) Gnathodus praebilineatus Belka, 1985, sample E. (e) Gnathodus bilineatus Roundy, 1926, sample E. (f) "Gnathodus"homopunctatus (Ziegler, 1960), sample E. (g) Lochriea nodosa (Bischoff, 1957), sample F. (h) Gnathodus bilineatus Roundy, 1926, sample F. (i) Gnathodus girtyi girtyi Haas, 1953, sample F. (j) Gnathodus girtyi girtyi Haas, 1953, sample F. (k) Gnathodus bilineatus Roundy, 1926, sample H. (l) “Gnathodus"homopunctatus (Ziegler, 1960), sample H.

The fossil-rich Erdbach Limestone has been interpreted as having been accumulated in a rather shallow but quiet environment (Amler et al., 2004), which is in marked contrast to some of the carbonate cover sediments of Rösenbeck, which either show sedimentary structures characteristic for tempestites or fossil-poor micrites (except for Goniatites crenistria). This means that the occurrence of Rösenbeck resembles the occurrence of Erdbach only superficially, i.e. in the position of Carboniferous carbonates in hollows within the Devonian reef limestone.

2. Do the sediments in the neptunian dykes from Rösenbeck belong to a short stratigraphic interval, and do the sediments in the neptunian dykes of Rösenbeck rep- resent, like the Erdbach Limestone in other places, a stratigraphic interval situated at the Tournaisian-Viséan boundary?

The samples from Rösenbeck belong to at least two different time intervals: (1) near the TournaisianViséan boundary (sample X) and (2) near the AsbianBrigantian boundary (samples A to $\mathrm{H}$ ). The age of sample $\mathrm{X}$ is proven by trilobites (P. Müller, personal communication, 2012), and the age of the other samples by conodonts and ammonoids. Ammonoids from samples A to $\mathrm{H}$ predominantly belong to the genus Goniatites (i.e. Goniatites crenistria to Goniatites spirifer zones of the late Asbian and early Brigantian) and are thus significantly older than the shales, which perform as the 


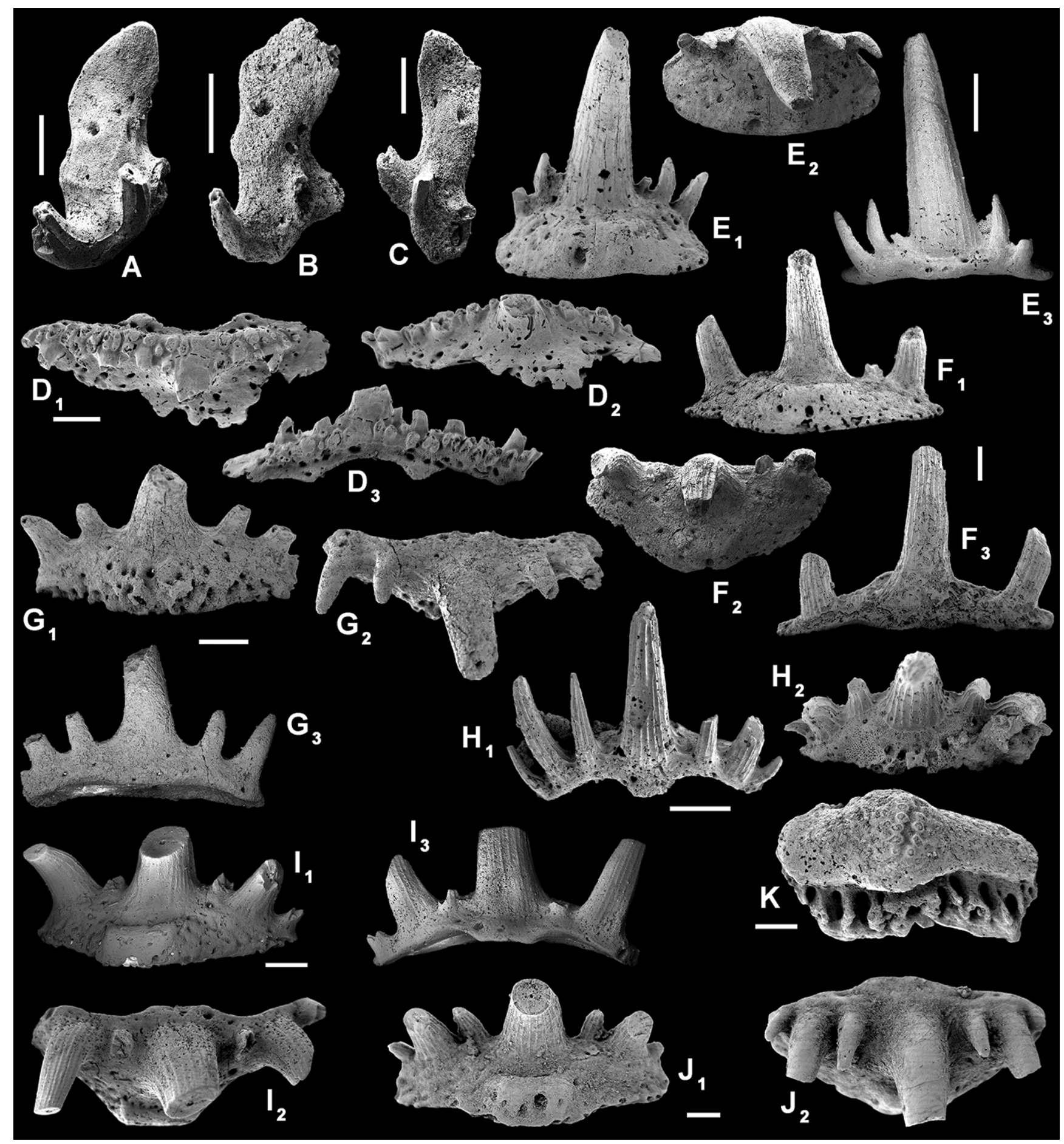

Figure 8. Chondrichthyan teeth from the Early Carboniferous dyke sediments of Rösenbeck. (a-c) Thrinacodus cf. gracia (Grogan and Lund, 2008). A, C, in lingual views, sample C; B, in lingual view, sample C. (d) ?Squatinactis sp., in occlusal ( $\left.\mathrm{D}_{1}\right)$, lingual ( $\left.\mathrm{D}_{2}\right)$, and labial $\left(D_{3}\right)$ views, sample C. (e-j) Denaea cf. fournieri Pruvost, 1922, in lingual $\left(E_{1}, F_{1}, G_{1}, H_{2}, I_{1}, J_{1}\right)$, occlusal ( $\left.E_{2}, F_{2}, G_{2}, I_{2}, J_{2}\right)$, and labial $\left(E_{3}, F_{3}, G_{3}, H_{1}, I_{3}\right)$ views, sample C. (k) Holocephali gen. et sp. indet. in lingual view, sample C. Scale bars: $0.4 \mathrm{~mm}$. 
A

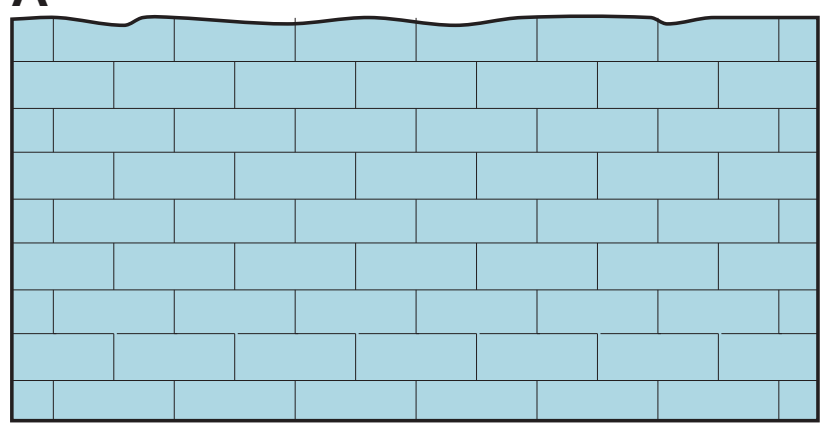

B

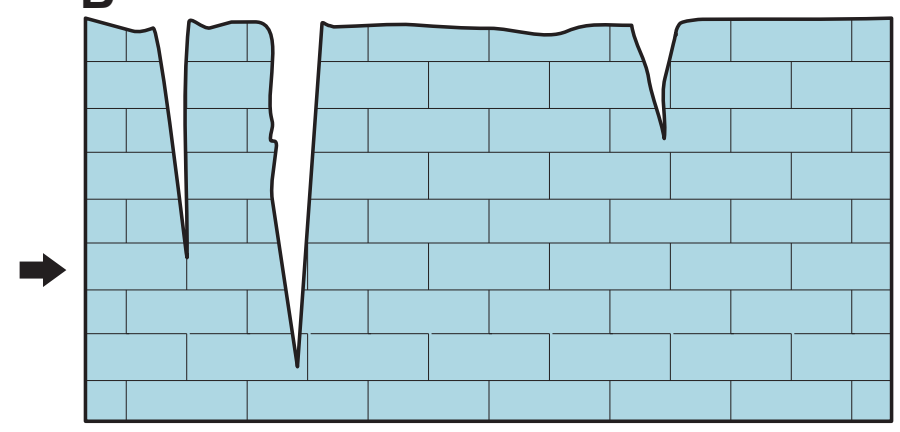

C

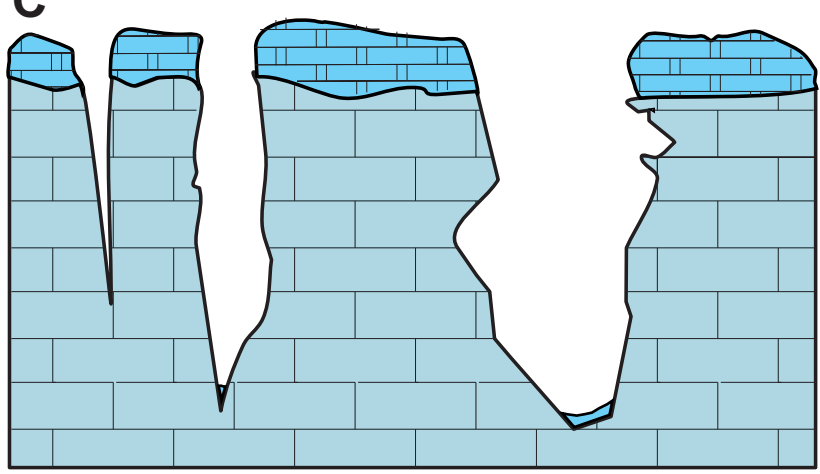

$E$

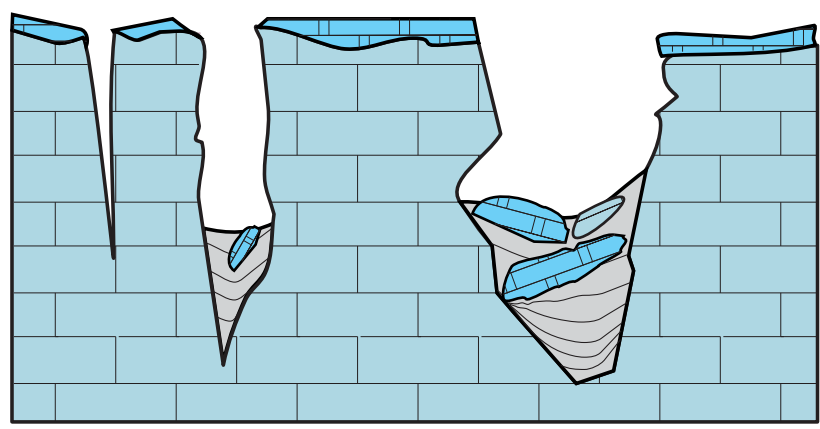

\section{Carboniferous limestone}

\section{Devonian reef limestone}

$\mathbf{F}$

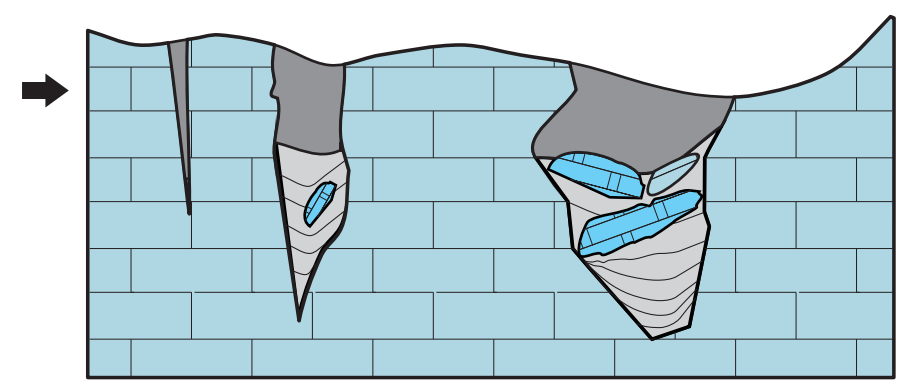

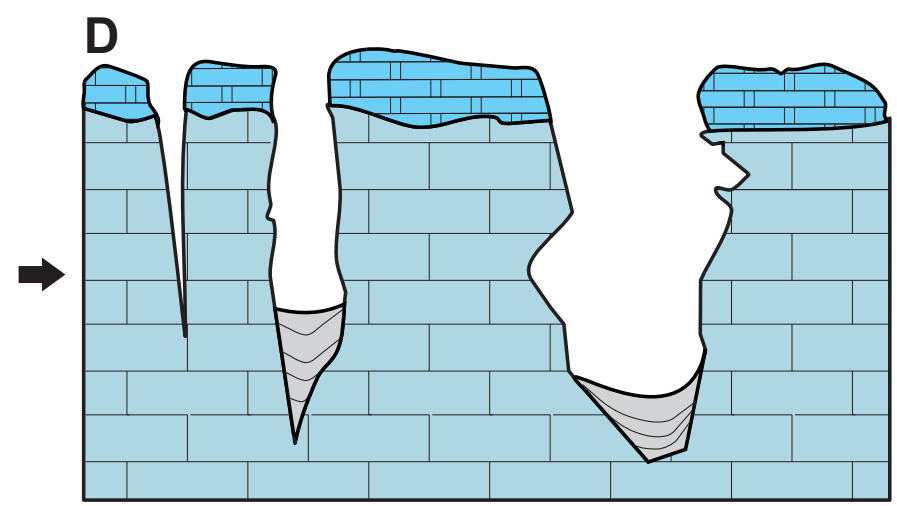

silt and mud

Carboniferous shales

Figure 9. Schematic diagram illustrating the genesis of the dykes and their sediments in the Rösenbeck quarry. (a) Early Late Devonian: end of reef limestone sedimentation. (b) Late Devonian to Tournaisian: collapse of the carbonate platform, formation of fissures and dykes. (c) Late Tournaisian to Viséan: accumulation of carbonates on top of the reef ruin, widening of the dykes. (d) Late Viséan: begin of filling of the dykes by shales. (e) Latest Viséan to early Serpukhovian: transport of eroded sediment blocks from the top of the reef ruin into the dykes. (f) Serpukhovian to Recent: complete filling of the dykes with mud, erosion of the reef complex. 
host sediments for the carbonate blocks and are probably early Serpukhovian in age.

Acknowledgements. We are indebted to Rheinkalk Messinghausen $\mathrm{GmbH} \& \mathrm{Co}$. KG for permission to investigate the Rösenbeck quarry. We also thank Sonny A. Walton (Berlin) for proofreading the manuscript and Michal Ginter (Warsaw) and Friedrich Wilhelm Luppold (Hanover) for reviewing an earlier version of the manuscript.

Edited by: F. Witzmann

Reviewed by: M. Ginter and F. W. Luppold

\section{References}

Amler, M. R. W., Heidelberger, D., and Müller, P.: Untiefen im Kulm-Meer - Die Fauna der unterkarbonischen Erdbach-Kalke, Hessen Archäologie, 2003, 11-14, 2004.

Bär, P.: Stratigraphie, Fazies und Tektonik am Briloner MassenkalkSattel (Ostsauerland), Dr. Thesis, Universität Gießen, 1966.

Bär, P.: Die ober-devonisch/unter-karbonische Schichtlücke über dem Massenkalk des Briloner und Messinghäuser Sattels (OstSauerland), Neues Jahrbuch für Geologie und Paläontologie, Abhandlungen, 131, 263-288, 1968.

Belka, Z.: Lower Carboniferous conodont biostratgraphy in the northeastern part of the Moravia-Silesia Basin, Acta Geol. Pol., 35, 33-61, 1985.

Belka, Z. and Lehmann, J.: Late Viséan/early Namurian conodont succession from the Esla area of the Cantabrian Mountains, Spain, Acta Geol. Pol., 48, 31-41, 1998.

Bischoff, G.: Die Conodonten-Stratigraphie des rhenoherzynischen Unterkarbons mit Berücksichtigung der Wocklumeria Stufe und der Devon/Karbon-Grenze, Abhandlungen des Hessischen Landesamtes für Bodenforschung, 19, 1-64, 1957.

Branson, E. B. and Mehl, M. G.: New and little known Carboniferous conodont genera, J. Paleontol., 15, 97-106, 1941.

Brinckmann, J. and Luppold, F. W.: Bericht über Befahrungen karbonischer Deckschichten des devonischen Briloner Riffkomplexes, speziell des Erbacher Kalkes, im Gebiet Madfeld (TK Madfeld - 1:25 000) am 27. und 28. April und am 22. September 2010, BGR-Bericht 0129788, 2010.

Brinckmann, J., Stoppel, D., and Luppold, F. W.: The Geology of the Brilon Reef Complex, Geologisches Jahrbuch, A 161, 2015.

Buggisch, W. and Krumm, S.: Palaeozoic cold seep carbonates from Europe and North Africa - an integrated isotopic and geochemical approach, Facies, 51, 566-583, 2005.

Buggisch, W. and Michl, S.: Early Carboniferous (Mississippian) Neptunian Dykes in Middle Devonian Reef Limestones of the Hahnstätten Quarry, Lahn Syncline, Rheinisches Schiefergebirge, Senckenbergiana lethaea, 82, 495-513, 2002.

Clausen, C.-D. and Leuteritz, K.: Übersicht über die Geologie des Warsteiner Sattels und seiner näheren Umgebung, Aufschluß, Sonderband, 29, 1-32, 1979.

Clausen, C.-D. and Leuteritz, K.: Erläuterungen zu Blatt 4516 Warstein., Geologische Karte Nordrhein-Westfalen 1:25000 Erläuterungen, 4516, 1-155, 1984.
Clausen, C.-D., Grebe, H., Leuteritz, K., and Wirth, W. Zur Altersstellung und palaogeographischen Bedeutung des Palaokarstes auf der Warsteiner Carbonatplatform, Neues Jahrbuch fur Geologie und Palaontologie, Monatshefte, 1978, 577-589, 1978.

Clausen, C.-D., Grebe, H., Leuteritz, K., Uffenorde, H., and Wirth, W.: Zur Paläogeographie, Tektonik und Karstmorphologie der südlichen und östlichen Warsteiner Carbonatplattform (Warsteiner Sattel, Rheinisches Schiefergebirge), Fortschritte in der Geologie von Rheinland und Westfalen, 30, 241-319, 1982.

Clausen, C.-D., Korn, D., and Luppold, F. W.: Litho- und Biofazies des mittel- bis oberdevonischen Karbonatprofils am Beringhäuser Tunnel (Messinghäuser Sattel, nördliches Rheinisches Schiefergebirge), Geologie und Paläontologie in Westfalen, 18, 7-65, 1991.

Dunham, R. J.: Classification of carbonate rocks according to depositional texture, in: Classification of carbonate rocks, in: Classification of carbonate rocks. Association of Petroleum Geologists Memoir, 1, edited by: Ham, W. E., 108-121, 1962.

Eichenberg, W. and Schneider, H.: Schichtenfolge und Fossilführung im Riff des Iberges und Winterberges (Devon, Karbon) bei Bad Grund im Harz, Paläontologische Zeitschrift, H. Schmidt-Festband, 25-28, 1962.

Embry, A. F. and Klovan, J. E.: Absolute water depth limits of Late Devonian paleoecological zones, Geol. Rundsch., 61, 672-686, 1972.

Foord, A. H. and Crick, G. C.: Catalogue of the fossil Cephalopoda in the British Museum (Natural History), Part III, Containing the Bactritidae and part of the suborder Ammonoidea, Printed by order of the Trustees, London, 303 pp., 1897.

Franke, W.: Fazies, Bau und Entwicklungsgeschichte des Iberger Riffes (Mitteldevon bis Unterkarbon III; NW-Harz, WDeutschland), Geologisches Jahrbuch A11, 1-127, 1973.

Franke, W.: The mid-European segment of he Variscides: tectonostratigraphic units, terrane boundaries and plate tectonic evolution, in: Orogenic processes: Quantification and Modelling in the Variscan Belt, Geological Society London, Special Publications, vol. 179, edited by: Franke, W., Geological Society, London, London, 35-61, 2000.

Füchtbauer, H. and Richter, D. K.: Relations between submarine fissures, internal breccias and mass flows during Triassic and earlier rifting periods, Geol. Rundsch., 72, 53-66, 1983.

Ginter, M., Hampe, O., and Duffin, C. J.: Chondrichthyes. Paleozoic Elasmobranchii: Teeth, in: Handbook of Paleoichthyology, edited by: Schultze, H.-P., Friedrich Pfeil, München, 168 pp., 2010.

Ginter, M., Duffin, C. J., Dean, M. T., and Korn, D.: Late Viséan pelagic chondrichthyans from northern Europe, Acta Palaeontol Pol., doi:10.4202/app.00084.2014, in press, 2015.

Gischler, E.: Das devonische Atoll von Iberg und Winterberg im Harz nach Ende des Riffwachstums, Geologisches Jahrbuch, A129, 1-193, 1992.

Gischler, E. and Korn, D.: Goniatiten des Ober-Viseums aus Decksedimenten des Iberger Riffes, Oberharz, Neues Jahrbuch für Geologie und Paläontologie, Abhandlungen,, 185, 271-288, 1992.

Gischler, E., Sandy, M. R., and Peckmann, J.: Ibergirhynchia contraria (F. A. Roemer, 1850), an Early Carboniferous seep-related rhynchonellide brachiopod from the Harz Mountains, Germany 
- A possible successor to Dzieduszyckia?, J. Paleontol., 77, 293303, 2003.

Groddeck, A. v.: Zur Kenntnis des Oberharzer Kulms, Jahrbuch der Preussischen Geologischen Landesanstalt, 1882, 44-67, 1883.

Grogan, E. D. and Lund, R.: A basal elasmobranch, Thrinacoselache gracia $\mathrm{n}$. gen and sp., (Thrinacodontidae, new family) from the Bear Gulch Limestone, Serpukhovian of Montana, USA, J. Vertebr. Paleontol., 28, 970-988, 2008.

Haas, W. H.: Conodonts of the Barnett Formation of Texas, U.S. Geological Survey, Professional Paper, 243F, 69-94, 1953.

Hahn, G.: Neue Trilobiten vom Winterberg/Harz (Unterkarbon), Senckenbergiana lethaea, 168, 163-189, 1967.

Hahn, G., Hahn, R., and Müller, P.: 100 Jahre Trilobiten-Forschung in den Erdbacher Kalken (Unter-Karbon). - Zusammenstellung bisheriger Ergebnisse und Beschreibung neuer Taxa, Geologica et Palaeontologica, 30, 147-194, 1996.

Herbig, H. G., Mestermann, B., and Korn, D.: Crenistria Event and Asbian-Brigantian Transition in the South Portuguese Zone - Sea Level Control on a Hemipelagic Late Dinantian Platform, Facies, 41, 183-196, 1999.

Holzapfel, E.: Cephalopoden-führenden Kalke des unteren Carbon von Erdbach-Breitscheid bei Herborn, Palaeontologische Abhandlungen, Neue Folge, 1, 1-74, 1889.

Huckriede, R.: Die unterkretazische Karsthöhlenfüllung von Nehden im Sauerland. 1. Geologische, paläozoologische und paläobotanische Befunde und Datierung, Geologica et Palaeontologica, 16, 183-242, 1982.

Jux, U.: Die devonischen Riffe im Rheinischen Schiefergebirge, Neues Jahrbuch für Geologie und Paläontologie, Abhandlungen, 110, 186-258, 1960.

Kayser, E.: Erläuterungen und Karte Blatt Dillenburg (5215). Geologische Karte von Preußen, Lieferung 101, 1-119, 1907.

Korn, D.: Lithostratigraphische Neugliederung der KulmSedimentgesteine im Rheinischen Schiefergebirge, Schriftenreihe der Deutschen Gesellschaft für Geowissenschaften, 379-383, 2006.

Korn, D.: Lithostratigraphy and biostratigraphy of the Kulm succession in the Rhenish Mountains, Z. Dtsch. Ges. Geowiss., 161, 431-453, 2010.

Korn, D. and Kaufmann, B.: A high-resolution relative time scale for the Visean Stage (Carboniferous) of the Kulm Basin (Rhenish Mountains, Germany), Geol. J., 44, 306-321, 2009.

Krebs, W.: Neue Ergebnisse zur Stratigraphie des Oberdevons und Unterkarbons in der südwestlichen Dillmulde (Rheinisches Schiefergebirge), Notizblatt des Hessischen Landesamtes für Bodenforschung, 88, 216-242, 1960.

Krebs, W.: Oberdevonische Conodonten im Unterkarbon des Rheinischen Schiefergebirges und des Harzes, Zeitschrift der Deutschen Geologischen Gesellschaft, 114, 57-84, 1962.

Krebs, W.: Reef development in the Devonian of the eastern Rhenish Slate Mountains, Germany, International symposium on the Devonian system, Calgary, 1, 295-306, 1967.

Krebs, W.: Die Lagerungsverhältnisse des Erdbacher Kalkes (Unterkarbon II) bei Langenaubach-Breitscheid (Rheinisches Schiefergebirge), Geotektonische Forschungen, 28, 72-103, 1968.

Krebs, W.: Die devonischen Riffe in Mitteleuropa, Mitteilungen Technische Universität Carola-Wilhelmina, 6, 1-12, 1971.
Krebs, W. and Wachendorf, H.: Der paläogeographisch-tektonische Entwicklungsgang des südlichen Warsteiner Komplexes, Rheinisches Schiefergebirge, Aufschluss Sonderband, 29, 33-47, 1979.

Machel, H.-G.: Faziesinterpretation des Briloner Riffs mit Hilfe eines Faziesmodells für devonische Riffkarbonate, Geologisches Jahrbuch, D95, 43-83, 1990.

Mestermann, B.: Mikrofazies, Paläogeographie und Eventgenese des crenistria-Horizontes (Obervisé, Rhenoherzynikum), Kölner Forum für Geologie und Paläontologie, 2, 1-77, 1998.

Moritz, W.: Fazies und Diagenese des Briloner Karbonatkomplexes anhand einiger ausgewählter Bohrungen., Dr. Thesis, Braunschweig, 1983.

Nemyrovska, T. I.: Late Visean/early Serpukhovian conodont succession from the Triollo section, Palencia (Cantabrian Mountains, Spain), Scripta Geologica, 129, 13-89, 2005.

Norman, D. B.: A Mass-Accumulation of Vertebrates from the Lower Cretaceous of Nehden (Sauerland), West Germany, P. Roy. Soc. Lond. B Bio., 230, 215-255, 1987.

Paeckelmann, W.: Der Briloner Massenkalksattel, die DevonCarbonmulde von Nehden und das Oberdevon-Culmgebiet von Rixen, Scharfenberg und Wülfte, Jahrbuch der Preussischen Geologischen Landesanstalt, 47, 19-35, 1926.

Paeckelmann, W. and Kühne, F.: Erläuterungen zu Blatt Madfeld Nr. 2586, Geologische Karte von Preussen und benachbarten deutschen Ländern 1:25000, Lieferung 341, 1-79, 1936.

Pas, D., Da Silva, A.-C., Cornet, P., Bultynck, P., Königshof, P., and Boulvain, F.: Sedimentary development of a continuous Middle Devonian to Mississippian section from the fore-reef fringe of the Brilon Reef Complex (Rheinisches Schiefergebirge, Germany), Facies, 59, 969-990, 2013.

Peckmann, J., Gischler, E., Oschmann, W., and Reitner, J.: An early carboniferous seep community and hydrocarbon-derived carbonates from the Harz Mountains, Germany, Geology, 29, 271-274, 2001.

Phillips, J.: Illustrations of the geology of Yorkshire, part II. The Mountain Limestone District, John Murray, London, 253 pp., 1836.

Pruvost, P.: Déscription de Denaea fournieri, sélacien nouveau du Marbre noir de Denée. Part 2 de G. Fournier, P. Pruvost, Découverte d'un poisson nouveau dans le marbre noir de Denée, Bulletin Académie Royal de Belgique, Classe des Sciences, 5, 213-218, 1922.

Richter, R. and Richter, E.: Die Trilobiten der Erdbach-Zone (Kulm) im Rheinischen Schiefergebirge und im Harz. I. Die Gattung Phillibole, Senckenbergiana, 30, 63-94, 1949.

Roemer, C. F.: Das Rheinische Übergangsgebirge, Eine paläontologisch-geognostische Darstellung, Hahn'sche Hofbuchhandlung, Hannover, 96 pp., 1844.

Roemer, F. A.: Beiträge zur geologischen Kenntniss des nordwestlichen Harzgebirges, Palaeontographica, 3, 1-67, 1850.

Roundy, P. V.: The microfauna in Mississippian formations of San Saba County, Texas, U.S. Geological Survey, Professional Paper, 146, 1-63, 1926.

Schindewolf, O. H.: Über ein neues Vorkommen unterkarbonischer Pericyclus-Schichten im Oberharz, Neues Jahrbuch für Geologie und Paläontologie, Abhandlungen, 93, 117-143, 1951.

Schülke, I. and Popp, A.: Microfacies development, sea-level change, and conodont stratigraphy of Famennian mid- to deep 
platform deposits of the Beringhauser Tunnel section (Rheinisches Schiefergebirge, Germany), Facies, 50, 647-664, 2005.

Schülke, I., Korn, D., Popp, A., and Ziegler, W.: Potential reference section for the Early/Middle Famennian boundary at the Beringhauser Tunnel (Rheinisches Schiefergebirge, NW Germany), Subcommission on Devonian Stratigraphy Newsletter, 19, 36-46, 2003.

Sedgwick, A. and Murchison, R. I.: On the Distribution and Classification of the older or Palaeozoic Deposits of the North of Germany and Belgium, and their comparison with Formations of the same age in the British Isles, Transactions of the Geological Society of London, second series, 6, 221-301, 1842.

Sievert-Doreck, H.: Crinoiden aus dem Unterkarbon des Oberharzes, Neues Jahrbuch für Geologie und Paläontologie, Abhandlungen, 93, 23-116, 1951.

Stein, R.: Geognostische Beschreibung der Umgebung von Brilon, Zeitschrift der Deutschen Geologischen Gesellschaft, 12, 208$272,1860$.

Stoppel, D., Korn, D., and Amler, M. R. W.: Der Nord- und Nordostrand des Rheinischen Schiefergebirges und das zentrale Sauerland, Schriftenreihe der Deutschen Gesellschaft für Geowissenschaften, 41, 330-358, 2006.

Uffenorde, H.: Zur Entwicklung des Warsteiner KarbonatKomplexes im Oberdevon und Unterkarbon (Nördliches Rheinisches Schiefergebirge), Neues Jahrbuch für Geologie und Paläontologie, Abhandlungen, 152, 75-111, 1976.
Uffenorde, H.: Resedimentäre Kalke des mittleren Unterkarbons im Warsteiner Sattel (Nördliches Rheinisches Schiefergebirge), Neues Jahrbuch für Geologie und Paläontologie, Abhandlungen, 153, 253-281, 1977.

von Dechen, H.: Geologische und Paläontologische Übersicht der Rheinprovinz und der Provinz Westfalen, sowie einiger angrenzender Gegenden, Erläuterungen, 2, 1-933, 1884.

Walliser, O. H. and Mitarbeiter: Zum Oberdevon und Unterkarbon von Erdbach-Langenaubach (SW-Dillmulde, Rheinisches Schiefergebirge), Notizblatt des Hessischen Landesamtes für Bodenforschung, 87, 120-132, 1958.

Warnke, K.: Microbial carbonate production in a starved basin: The crenistria Limestone of the upper Visean German Kulm facies, Palaeogeogr. Palaeocl., 130, 209-225, 1997.

Witzmann, F., Dorka, M., and Korn, D.: A juvenile Early Carboniferous (Viséan) coelacanth from Rösenbeck (Rhenish Mountains, Germany) with derived postcranial characters, Foss. Rec., 13, 309-316, doi:10.5194/fr-13-309-2010, 2010.

Ziegler, W.: Die Conodonten aus den Geröllen des Zechsteinkonglomerates von Rossenray (südwestlich Rheinberg/Niederrhein), Fortschritte in der Geologie von Rheinland und Westfalen, 6, 1$15,1960$. 